\title{
PENGGUNAAN E-MONEY BRIZZI SEBAGAI ALAT PEMBAYARAN MENURUT HUKUM EKONOMI SYARIAH (STUDI ANALISIS TERHADAP PRODUK E-MONEY BRIZZI PADA BANK BRI KANTOR CABANG BLORA)
}

\author{
M. Zubaidi \\ Suhartono \\ Universitas Muhammadiyah Surabaya \\ Email: zubaidimuhammad16@gmail.com
}

\begin{abstract}
This research discusses and analyzes the mechanism of using Brizzi E-money issued by BRI Bank Blora Branch Office, as well as the perspective of Sharia Economic Law on the use of the card mechanism. Especially the electronic payment instruments issued by Bank BRI namely E-Money Brizzi. This research not only examines law theoretically, but also looks at it from the practice and application side in the field. This type of research is field research, namely research activities carried out at BRI Bank Blora Branch Office. The research approach which used is a qualitative descriptive research approach, which is an approach used to understand the phenomena about what is experienced by the subject and object of research.

The results of this study concluded that the use of Brizzi E-money cards had met the legal and legal requirements for consent. In addition, when viewed from the aspect of cases that in validate the legality of the sale and purchase law, the use of Brizzi e-money cards in the sale and purchase transaction does not include elements that cancel the sale and purchase such as elements of gharar, maysir, and usury. The deduction of administrative funds due to transactions using the Brizzi e-money card has a similarity to the wakalah bil ujrah system in Sharia Economic Law. However, base on the results of the analysis conducted by the author, it is found that th euse of Brizzi e-money cards is not in accordance with the theory of wadi'ah dueto the unfulfillment of conditions and harmony in theuse, alsois not in line with the concept of wadi'ah yad amanah and wadi ' ah yad dhamanah from the aspect of the burden of responsibility for the party entrusted. Besides that, the use of Brizzi e-money cards is also not in accordance with the qardh theory. This is because in addition to not fulfilling one of the pillars and qardh validity requirements, also in the qardha fter the contract is said, the goods or asset swhich become the object of qardh automatically be come the property of the party receiving the loan. Where as in the system of using Brizzi e-money cards, the electronic money that is on the card after being deposited to the bank remains the property of the card holder.
\end{abstract}

Keywords: E-Money, Brizzi, Sharia Economic Law, BRI Bank.

\section{PENDAHULUAN}

Seiring dengan perkembangan zaman, model dan cara pelaksanaan jual beli serta cara pembayaran juga mengikuti trend perubahan yang semakin modern dan canggih. Perkembangan teknologi informasi membuat hubungan antar manusia di dunia menjadi tanpa batas, dampaknya terhadap perubahan dalam hal ekonomi menjadi sangat cepat, dalam percepatan ini jual beli dan pembayaran dapat dilaksakan melalui transaksi elektronik yang tidak dibatasi oleh waktu dan tempat. Untuk menyesuaikan perkembangan transaksi sebagaimana dijelaskan di atas dengan kebutuhan masyarakat terhadapnya, maka akhir-akhir 
ini sistem

pembayaran

cashless (pembayaran non tunai) semakin digalakkan pada berbagai area. Sebagai contoh di wilayah Jakarta, misalnya, sistem cashless ini sudah mulai diberlakukan sejak 3 tahun silam untuk pembayaran bagi pengguna alat transportasi seperti Commuter Line dan Bus Trans Jakarta.

Kemudian Bank Indonesia juga akhirnya mengumumkan secara resmi kalau per tanggal 31 Oktober 2017, seluruh jalan tol di Indonesia (gerbanggerbang tol) hanya akan menerima pembayaran menggunakan uang elektronik. Hal ini tentu membuat banyak orang yang sebelumnya tidak 'melek' uang elektronik, mau tidak mau harus mempersiapkan diri dengan memilikinya. Sebenarnya penggunaan uang elektronik sebagai pembayaran sudah lama dilakukan melalui penggunaan kartu kredit dan kartu debit, namun berbeda dengan dua kartu tersebut, kini setiap orang bisa menggunakan uang eletronik tanpa harus menjadi nasabah bank terlebih dahulu. Maraknya penggunaan uang elektronik tentu membuat kita juga harus mencermati plus minus (kelebihan dan kekurangan) penggunaan sistem pembayaran yang satu ini.

Dalam perkembangan selanjutnya berdasarkan ijin dari Bank Indonesia tersebut di atas, maka beberapa jenis $E$ money yang diterbitkan oleh perbankan, operator seluler, dan pihak lainnya, untuk transaksi pembayaran baik dalam jual beli maupun pembayaran yang lain, maka terbitlah berbagai macam jenis e-money yang diantaranya telah dikenal luas di tengah-tengah masyarakat. Salah satunya adalah Brizzi, yang diterbitkan oleh Bank BRI. Satu hal yang menarik dari kartu Brizzi keluaran dari Bank BRI ini adalah bisa dimiliki oleh siapapun tanpa terlebih dahulu harus memiliki rekening di Bank BRI. Dan tidak hanya itu saja, di dalamnya juga sering sekali memberikan promo menarik bagi para penggunanya.

Di samping berbagai macam kelebihan tersebut di atas, uang elektronik (e-money) bukan tidak memiliki kekurangan atau kelemahan. Sebagaimana sebuah produk pabrikan yang dengan segala kelebihan dan kecanggihannya bisa kita nikmati, uang elektronik (e-money) juga memiliki kekurangan dan kelemahan. Adapun kekurangan dan kelemahan pembayaran dengan memakai uang elektronik antara lain adalah: Pertama, berisiko mengalami peretasan (cybercrime) yakni kejahatan dunia maya, dikarenakan berhubungan langsung dengan penggunaaan internet yang tidak luput dari malware (kerusakan sistem pada data base) atau hacker(penyusup dan perusak data internet).Kedua, mudah hilang dan atau berpindah tangan, kartu atau aplikasi e-moneydimana kita menyimpan uang bisa saja hilang, dikarenakan kesalahan software dan faktor lain di luar pengetahuan kita. Ketiga, menyuburkan riba dengan cara-cara tersembunyi atas pengelolaan uang yang ada (masih tersisa sebagai saldo) dalam kartu (e-money) tersebut.

Selain itu sistem pembayaran dengan alat bayar yang canggih yang patut diduga ada pengelolaan yang hanya menguntungkan pihak tertentu yang bersembunyi di balik $e$-money, pemilik $e$ money sama sekali tidak tahu saldo yang mengendap di dalam kartu yang disimpannya itu dikelola oleh siapa (bank atau pihak lain diluar bank), kemudian dipergunakan (dikelola) untuk membiayai kegiatan bisnis macam apa dan bagaimana juga tidak tahu.

Jika pemanfaatan uang yang masih mengendap dalam e-money tersebut ternyata dipergunakan oleh bank atau pihak penerbit untuk membiayai kegiatan usaha (bisnis) yang halal dan sesuai syariah maka tidak ada masalah, meskipun pemilik uang tidak mendapatkan bagian keuntungan apapun karena memang tidak ada perjanjian/tidak diperjanjikan di muka. Namun jika uang yang masih mengendap sebagai saldo dalam kartu e-money tersebut dipergunakan untuk membiayai kegiatan usaha (bisnis) yang tidak halal 
dan tidak sesuai syariah maka ada semacam riba baru dalam dunia perbankan dan juga transaksi jual beli dan pembayaran yang berbasis informasi dan transaksi elektronik.

Sejauh ini apa yang penulis ketahui tentang menggunaan e-moneyBrizzi yang penulis anggap tidak sejalan dengan prinsip-prinsip transaksi dalam Hukum Ekonomi Syariah dapat dijelaskan melalui beberapa poin berikut ini: (1) Berdasarkan konsep jual beli dalam Hukum ekonomi syariah, dijelaskan bahwa objek akad, termasuk alat pembayaran haruslah riil dan dapat diserahterimakan, jual beli harus dengan akad yang jelas. Dalam hal ini jual beli yang menggunakan fasilitas e-money Brizzi itu tidak memenuhi persyaratan sebagaimana ditentukan oleh Hukum Ekonomi Syariah. ${ }^{1}$ (2) Adanya ketentuan bahwa apabila kartu e-money Brizzi tidak digunakan dalam jangka waktu 12 bulan, maka apabila dalam kartu tersebut masih ada saldo yang kurang dari Rp. 25.000, maka saldo tersebut menjadi milik bank. ${ }^{2}$ Hal ini menurut penulis tampak bertentangan dengan konsep wadiah (penitipan) dalam Hukum Ekonomi Syariah.

Berangkat dari latar belakang dan permasalahan yang telah penulis paparkan tersebut, penulis menganggap bahwa masalah tersebut sangat penting untuk dilakukan penelitian, karena itu penulis tertarik untuk melakukan kajian lebih dalam dan utuh terhadap masalah tersebut. Adapun masalah-masalah yang akan dijawab dalam penelitian ini dibatasi pada beberaparumusan berikut ini: (1) Bagaimana penggunaan E-money Brizzi di Bank BRI Kantor Cabang Blora? (2) Bagaimana perspektif Hukum Ekonomi Syariah terhadap penggunaan $E$ moneyBrizzi dari Bank BRI Kantor Cabang Blora?

${ }^{1}$ Kompilasi Hukum Ekonomi Syariah, bab II, pasal 22-25.

${ }^{2}$ https://www.moneysmart.id/dari-brizzi-flazze-money-hingga-tapcash-mana-yang-lebih-unggul/. Data diakses pada tanggal 3 Desember 2019.

\section{METODE PENELITIAN}

Penelitian ini adalah penelitian lapangan (field research) yaitu kegiatan penelitian yang dilakukan di Bank BRI KC Blora. Pendekatan penelitian yang digunakan adalah pendekatan penelitian deskriptif kualitatif, yaitu suatu pendekatan yang digunakan untuk memahami fenomena tentang apa yang di alami oleh subjek dan objek penelitian. ${ }^{3}$ Penelitian ini merupakan penelitian kualitatif, karena mengandalkan observasi, wawancara, studi dokumentasi dan arsip-arsip yang terkait dengan permasalahan praktek pembayaran dengan memakai alat bayar berbasis informasi dan transaksi elektronik, khususnya penggunaan E-money Brizzi yang diterbitkan oleh Bank BRI. Oleh karena itu, focus penelitian ini ditujukan untuk memperoleh kejelasan mengenai praktek pembayaran dengan memakai alat bayar berbasis informasi dan transaksi elektronik khususnya alat bayar elektronik yang diterbitkan oleh Bank BRI yaitue-Money Brizzi (dalam penelitian ini yaitu pada Bank BRI Kantor Cabang Blora) serta memperoleh kejelasan mengenai status hokum aplikasi pembayaran dengan alat bayar berbasis informasi dan transaksi elektronik atau uang elektronik khususnya berkenaan dengan penerbitan dan penggunaan e-Money Brizzioleh Bank Rakyat Indonesia (BRI). Artinya, penelitian ini tidak hanya mengkaji hokum secara teoritis, akan tetapi juga melihat dari sisi praktik dan penerapan di lapangan.

Sumber data primer merupakan sumber data yang bersifat autoritatif atau memiliki otoritas dalam menentukan suatu hukum. Karena itu selain sumber data yang diperoleh dari hasil wawancara, observasi dan dokumentasi, sumber data primer lainnya yang digunakan dalam

${ }^{3}$ Lexi J. Moleong, Metodologi Penelitian Kualitatif, (Bandung: Rosda Karya, 2007), 6 dan 11. 
penelitian ini terdiri dari peraturan perundang-undangan, catatan resmi, risalah dalam pembuatan perundangundangan dan putusan hakim terkait masalah yang dikaji. ${ }^{4}$ Dalam penelitian ini bahan hukum primer yang digunakan adalah sebagai berikut: (a) Undang-undang No. 10 Tahun 1998 Tentang Perubahan Atas Undang -UndangNomor 7 Tahun 1992 tentang Perbankan. (b) UndangUndang No. 21 Tahun 2008 Tentang Perbankan Syariah. (c) PERMA RI Nomor 2 Tahun 2008 Tentang Kompilasi Hukum Ekonomi Syariah. (d) Fatwa DSN NO: 116/DSN-MUI/IX/2017 Tentang Uang Elektronik Syariah.

Di samping itu dalam penelitian ini penulis akan menggali dari sumber-sumber informasi atau pemberi informasi yang akan penulis jadikan sebagai bahan kajian dan juga nantinya bahan analisa khususnya terhadap penerbitan dan penggunaaneMoney Brizzi oleh Bank BRI dan juga penerbitan serta penggunaan kartu $e$ money oleh bank atau lembaganon bank pada umumnya. Sumber-sumber informasi yang akan penulis eksplor pada saatnya nanti yaitu: (a) Key Informan (Informan kunci). Dalam penelitian ini sebagai kunci informan yang akan penulis mintai keterangan dan semua informasi pokok mengenai penerbitan dan penggunaan $e$ Money Brizzi yang diterbitkan oleh Bank BRI adalah Bapak Kepala Kantor BRI Cabang Blora. (b) Customer Servis. Disamping Key Informan atau informan kunci dalam penelitian ini penulis juga akan mengeksplor berbagai keterangan mengenai penerbitan dan penggunaan $e$ Money Brizzi yang diterbitkan oleh Bank BRI kepadapetugas Customer Servis pada Bank BRI Kantor Cabang Blora. Sumber data primer lainnya akan penulis ambil dari hasil observasi dan dokumentasi di lokasipenelitian.

Adapun teknik pengumpulan data yang dipilih dalam penelitian ini akan

\footnotetext{
${ }^{4}$ Peter Mahmud Marzuki, Penelitian Hukum, (Jakarta: Kencana Prenada Media Group, 2011), 141.
}

antara lain adalah teknik dokumentasi, observasi, dan wawancara. Sedangkan teknik analisis data akan penulis lakukan melalui proses editing data, pengorganisasian data, analisis data, serta penemuan hasil dan kesimpulan.

\section{PEMBAHASAN}

\section{A. Penggunaan E-Money Brizzi Sebagai Alat Pembayaran \\ E-Money Brizzi adalah uang} elektronik yang diciptakan oleh perusahaan Bank BRI sebagai pengganti uang tunai yang memiliki fungsi sebagai alat pembayaran yang dapat digunakan untuk membayar berbagai bentuk transaksi seperti belanja (purchase) atau transaksi lainnya yang dilakukan di penyedia barang maupun jasa. E-Money Brizzi merupakan sebuah produk uang elektronik atau eMoney yang berbentuk kartu yang diterbitkan oleh BRI untuk melayani dan memprosestransaksi digital yang dilakukan baik oleh nasabah BRI sendiri maupun oleh masyarakat umum. Sebagai sebuah produk e-Money, masyarakat dapat menggunakan E-Money Brizzi sebagai pengganti uang tunai untuk melayani berbagai transaksi pembayaran sehari-hari.

Sebagaimana layaknya suatu produk kartu e-Money lainnya, kartu E-Money Brizzi dilengkapi dengan teknologi (Radio Frequency Identification) RFID yang memungkinkan pengguna kartu tersebut atau pemilik kartu untuk melakukan transaksi pembayaran hanya dengan menempelkan kartu kemesin pembaca dan transaksi dapat langsung diproses.

Untuk mendapatkan e-money Brizzi tersebut, tidak ada prosedur dan syarat khusus yang harus dipenuhi bagi setiap nasabah yang akan mengajukannya. Menurut keterangan yang penulis dapat kandari kepala bagian E Banking and Card BRI Wilayah Blora Jawa Tengah, untuk mendapatkan kartu Brizzi tersebut sebenarnya tidak sulit, tetapi cukup melakukan Registrasi di Kantor Cabang, Kantor Cabang Pembantu, Kantor Kas atau Kantor Unit BRI dan merchants tertentu 
yang sudah bekerjasama dengan pihak bank BRI seperti di Indomaret dan sebagainya. ${ }^{5}$ Namun, menurutnya untuk masalah keamanan kartu tersebut, tergantung pada bagaimana sipengguna menjaganya. Karena itulah, kartu tersebut harus dijaga agar supaya tidak sampai jatuh ketangan yang salah.

Untuk mendapatkan kartu e-money Brizzi tersebut, selain calon nasabah harus melakukan pendaftaran kekantor-kantor BRI, BRI Wilayah Blora sendiri juga melakukan promo dan penjualan kartu tersebut di berbagai iven, baik itu iven tingkat besar maupun iven tingkat local. Jelasnya, kata responden yang penulis wawancarai, untuk penggunaan pertama kartu tersebut biasanya terbatas hanya dilingkungan kantor sendiri. Untuk harga kartu Brizzi sendiri sangatlah terjangkau bagi masyarakat umum, yaitu hanya dengan Rp 20.000 saja siapapun sudah bias memiliki kartu tersebut dan menggunakannya. ${ }^{6}$

Dalam mengajukan pembuatan kartu e-money Brizzi tersebut, sebenarnya tidak ada prosedur atau peraturan yang rumit, karena calon nasabah hanya cukup pergi kekantor BRI terdekat, baik itu kantor cabang, kantor unit, atau merchants yang telah bekerjasama dengan bank BRI, membayar saldo minimum, menunjukkan kartu identitas, maka kartu e-money Brizzi sudah dapat di miliki. Sejauh ini ada beberapa tempat yang menyediakan kartu e-money Brizzi dimana masyarakat bias mendapatkannya, yaitu di kantor BRI terdekat, minimarket seperti Indomaret atau Alfamart, sales representative kartu emoney Brizzi di beberapa gerbang tol tertentu, stasiun, halte-halte transjakarta, vending machine untuk e-money, serta di merchant-merchant online atau online market place.

\footnotetext{
${ }^{5}$ Wawancara dengan Novita, kepala bagian E BankingandCard BRI Wilayah Blora Jawa Tengah pada tanggal 5 Desember 2019.

${ }^{6}$ Wawancara dengan Novita, kepala bagian E BankingandCard BRI Wilayah Blora Jawa Tengah pada tanggal 5 Desember 2019.
}

Bagi penggunaa kartu Brizzi, menurut kepala BRI Kantor Cabang Blora, ada beberapa ketentuan umum yang perlu diperhatikan, ${ }^{7}$ di antaranya:

a. E-Money Brizzi menggunakan satuan hitung mata uang rupiah dan hanya dapat digunakan di Indonesia.

b. E-Money Brizzi bukan merupakan produk simpanan dan dana yang ada di dalamnya tidak diberikan bunga sebagaimana dana simpanan, serta tidak ada jaminan oleh Lembaga Penjamin Simpanan (LPS).

c. Kepemilikan E-Money Brizzi dapat dipindahkan atau diwakilkan tanpa peraturan apapun, dan hanya dengan cara memberikan fisik kartu E-Money Brizzi kepada orang lain yang dikehendaki pemiliknya.

d. E-Money Brizzi yang hilang, dicuriataumungkindipergunakan oleh pihak lain yang tidak berwenang, maka pihak bank tidak dapat melakukan pemblokiran maupun diganti dengan kartu yang baru. Segala akibat atas kartu EMoney Brizzi yang hilang maupun dicuri sepenuhnya menjadi tanggungjawab pemegang kartu tersebut.

e. Pemegang Kartu E-Money Brizzi hanya dapat menggunakan kartu tersebut untuk transaksi pembayaran selama dana yang tersimpan pada kartu tersebut masih cukup.

f. Kepemilikan kartu E-Money Brizzi tidak dikenakan biaya administrasi bulanan (sebagaimana yang dikenakan pada kartu ATM).

g. Pemegang Kartu diharuskan memelihara fisik kartu E-Money Brizzi sehingga tidak rusak, patah, sehingga nomor kartu masih dapat diidentifikasikan.

h. Data penggunaan kartu, seperti keterangan dan perhitungan dari Bank BRI yang berkaitan dengan transaksi pembayaran, sertatransaksi-transaksi lainnya yang berhubungan dengan saldo E-

\footnotetext{
${ }^{7}$ Wawancara dengan Muhammad Naufal Thariq, kepala cabang BRI Kantor Cabang Blora Jawa Tengah pada tanggal 5 Desember 2019.
} 
Money Brizzi sebagai akibat pemakaiannya menjadi bukti yang mengikat, kecuali apabila dapat dibuktikan sebaliknya.

i. Penggunakartu E-Money Brizzi diwajibkan tunduk pada ketentuanketentuan yang berlaku yang ditetapkan oleh Bank BRI beserta syarat-syarat dan ketentuan-ketentuan yang mengatur semua produk jasa atau fasilitas, sertaTransaksi Pembayaran ataupun Transaksi Top up yang dicakup oleh E-Money Brizzi, termasuk setiap perubahan yang mungkin terjadi akan diinformasikan terlebih dahulu oleh perusahaan, yaitu Bank BRI.

Lebih jauh lagi kepala BRI Kantor Cabang Blora menjelaskan bahwa untuk transaksi e-money Brizzi ini dilakukan berdasarkan teknologi chip dengan saldo maksimal Rp 1 juta. Menurutnya, untuk saat ini pihak bank BRI hanya bias membatasi pengisian hanya sebesar Rp 1 juta dan belum bias lebih dari itu. Kartu emoney Brizzi merupakan uang isi ulang pengganti uang tunai yang fungsinya adalah sebagai alat pembayaran. Jadi, menurutnya jika e-money Brizzi sudah habis saldonya, maka perlu untuk mengisinya kembali, dan caranya pun sangatlah mudah dan bias dilakukan di mana saja. Kartu e-money Brizzi dapat diisi ulang di ATM BRI atau dengan ATM Bank lain yang berlogo Link, Atm Bersama, ATM Prima. Tidakhanyaitu, untuk melakukan pengisian saldo kartu emoney Brizzi juga bias dilakukan melalui Mobile Banking BRI, Internet Banking BRI dan juga EDC BRI yang ada di seluruh merchant e-money Brizzi misalnya dengan menggunakan kartu debit BRI atau kartu debit bank lainnya. ${ }^{8}$

\section{B. Penggunaan E-money Brizzi Menurut Hukum Ekonomi Syariah}

Seperti yang telah dijelaskan pada bab sebelumnya bahwa Hukum Ekonomi

\footnotetext{
${ }^{8}$ Wawancara dengan Muhammad Naufal Thariq, kepala cabang BRI Kantor Cabang Blora Jawa Tengah pada tanggal 5 Desember 2019.
}

Syariah merupakan peraturan yang mengatur aktifitas atau perilaku manusia secara actual dan empirical, baik dalam ranah produksi, distribusi, ataupun konsumsi berdasarkan syariah Islam yang bersumber dari al-Qur'an dan Sunnah serta ijma' para ulama dengan tujuan untuk mencapai kebahagiaan dunia dan akhirat.

Ekonomi syariah bukanlah sekedar nilai etika yang bersifat normatif, tetapi juga bersifat positif karena ia mengkaji aktifitas actual manusia, problem-problem ekonomi masyarakat dalam perspektif Islam. Dalam ekonomi syariah, baik konsumen maupun produsen bukanlah raja. Perilaku keduanya harus dituntun oleh kesejahteraan umum, individual, dan social sebagaimana yang telah ditetapkan oleh syariah Islam. ${ }^{9}$

Berlandaskan pada pemikiran tersebut maka dapat dikatakan bahwa Islam memiliki system ekonomi yang secara fundamental berbeda dari system ekonomi yang lain. Sistem ekonomi Islam memiliki akar syariah yang membentuk pandangan dunia, strategi, dan sasaran yang berbeda dengan system sekuler yang menguasai dunia pada saat ini. Konsep ekonomi syariah sasarannya tidak sekedar berdasarkan pada aspek material semata, tetapi juga mencakup aspek-aspek immaterial seperti kebahagiaan manusia, kehidupan yang sejahtera, persaudaraan, keadilan sosial dan ekonomi, serta berbagai kebutuhan spiritual manusia lainnya.

Untuk mewujudkan konsep-konsep di atas, Hukum Ekonomi Syariah memiliki seperangkat aturan teoritis yang mesti dipatuhi. Adapun dalam penelitian ini penulis hanya akan menggunakan beberapa teori saja dalam Hukum Ekonomi Syariah untuk melihat apakah penggunaan kartu e-money Brizzi sebagaimana yang telah dibahas pada bagian sebelumnya, sejalan dengan teoriteori dalam Hukum Ekonomi Syariah atau

\footnotetext{
${ }^{9}$ Abdul Manan. Hukum Ekonomi Syariah Dalam Perspektif Kewenangan Peradilan Agama. (Jakarta: Kencana, 2012), 30.
} 
sebaliknya. Kajian ini sangat penting karena kesesuaian ataupun ketidak sesuaian penggunaan kartu e-money Brizzi akan turut menentukan keabsahan transaksi serta kualitas materi (kehalalan) yang dihasilkan dari transaksi tersebut dalam perspektif hukum Islam secara umum.

\section{Penggunaan E-money Brizzi Menurut Teori Wadi'ah}

Wadi'ah menurut bahasa adalah sesuatu yang ditempatkan bukan pada pemiliknya supaya dijaga, atau barang yang dititipkan orang lain untuk dijaga atau dipelihara. Sedangkan menurut istilah wadi'ah adalah pemberian otoritas pemilikan suatu barang kepada orang lain agar dijaga secara jelas dan tegas. Para ulama dari kalangan mazhab Maliki, Syafi'i, dan Hambali (jumhur ulama) mendefinisikan wadi'ah sebagai mewakilkan orang lain untuk memelihara harta tertentu dengan cara tertentu. Sedangkan ulama mazhab Hanafi berpendapat wadi'ah adalah mengikut sertakan orang lain dalam memelihara harta baik dengan ungkapan yang jelas, melalui tindakan, maupun isyarat. MenurutSyeikhTaqiyudin Abu Bakar Bin Muhammad al-Husaini, wadi'ah adalah sesuatu yang dititipkan (dipercayakan) oleh pemiliknya kepada orang lain. Menurut Zuhaily, Wadi'ah adalah pemberian mandate untuk menjaga sebuah barang yang dimiliki seseorang dengan cara tertentu. ${ }^{10}$

Dari berbagai definisi wadi'ah tersebut dapat diambil kesimpulan bahwa pengertian wadi'ah adalah suatu akad antara dua pihak dimana pihak yang pertama menyerahkan tugas dan kekuasaan atau wewenang untuk menjaga suatu barang yang dimiliki oleh pihak pertama kepada pihak yang lain tanpa imbalan. Adapun barang yang diserahkan tersebut adalah amanah yang harus dijaga dan

\footnotetext{
${ }^{10}$ WahbahZuhaili, Fiqh Islam waAdillatuh, juz 5, (Damascus: Dar al-Fikr, 1986), 42.
}

dipelihara dengan baik meskipun pihak yang diberi amanah tidak menerimaupah.

Wadi'ah terbagi menjadi dua kelompok, yakni wadi'ah yad amanah dan wadi'ah yad dhamanah.

Wadi'ah yad amanah adalah akad penitipan suatu barang atau uang dimana pihak penerima titipan tidak diperbolehkan menggunakan barang atau uang tersebut. Adapun orang yang dititipi barang (wadi') tidak bertanggung jawab jika terjadi kehilangan atau kerusakan pada barang titipan tersebut selama bukan akibat dari kelalaian atau kecerobohan yang bersangkutan dalam menjaga dan memelihara barang titipan. Hal ini dapatditemukan landasannya dalam sebuah Hadis Rasulullah saw yang artinya: "Jaminan pertanngungjawaban tidak (boleh) diminta dari peminjam yang tidak menyalahgunakan (pinjaman) dan penerima (barang) titipan yang tidak lalai. ${ }^{11}$

Wadi'ah yad dhamanah adalah suatu bentuk akad penitipan barang atau uang yang mana pihak penerima titipan tersebut dengan atau tanpa seizin pemilik barang dapat menggunakan atau memanfaatkan barang atau uang yang dititipkan tersebut, dan penerima titipan diwajibkan bertanggungjawab terhadap kehilangan maupun kerusakan barang yang dititipkan tersebut. Akad wadi'ah yad dhamanah tersebut berlaku apabila orang yang dititipi barang melakukan penggunaan misalnya usaha bisnis tertentu setelah mendapatkan izin dari orang yang menitipkan barang tersebut. Sehingga dengan demikian penerima titipan, baik itu perorangan maupun lembaga keuangan bertanggungjawab atas segala kerusakan atau kehilangan yang terjadi pada barang yang dititipkan tersebut. ${ }^{12}$

\footnotetext{
${ }^{11}$ Muhammad, system dan Prosedur Oprasional Perbankan Syari'ah, (Yogyakarta: UII Press, 2000), 8 .

${ }^{12}$ Mohammad Firdaus, dkk, Konsep dan Implementasi Bank Syari'ah, (Jakarta: Renainsan, 2005 ), 8. Menurut WahbahZuhaili, status titipan dapat berubah dari amanah kepada tanggungan
} 
Penggunaan kartu e-money Brizzi apabila dilihat dari sudut pandang teori wadi'ah, menurut penulis tidak sesuai dengan teori wadi'ah karena beberapa perkara sebagai berikut:

(1) Aspekrukun dan syaratwadi'ah. Dalam pelaksanaan wadi'ah yang sah maka harus memenuhi rukun dan syarat tertentu, di antaranya: (a) Barang yang dititipkan disyaratkan harus barang yang dapat dimiliki menurut syara'. (b) Orang yang menitipkan dan yang menerima titipan disyaratkan telah baligh, berakal, dan syarat-syarat lainnya yang sesuai dengan syarat berwakil. (c) Adanya pernyataan serah terima (ijab dan qabul) dimana dalam hal ini disyaratkan bahwa pernyataan yang dimaksud harus dapat dimengerti dengan jelas oleh kedua belah pihak yang melakukanakad. Apabila dilihat dari aspek rukun dan syarat wadi'ah tersebut, penggunaan kartu e-money Brizzi tidak memenuhi rukun dan syarat yang

(dhaman) karena terjadinya beberapa keadaan sebagai berikut: (1) Orang yang menerima titipan tidak menjaga dan memelihara barang yang dititipkan kepadanya dengan baik sehingga mengakibatkan kerusakan atau kehilangan barang tersebut. (2) Orang yang menerima titipan dengan sengaja tanpa udzurapapun menitipkan barang yang dititipkan kepadanya kepada orang lain yang tidak mampu menjaga dan memelihara barang tersebut. (3) Orang yang menerima titipan dengan sengaja menggunakan atau mengambil manfaat dari barang yang dititipkan kepadanya sehingga menimbulkan kerugian bagi pemiliknya, maka ia wajib mengganti kerugian tersebut. (4) Orang yang menerima titipan mengingkari akad wadi'ah,. Misalnya pemilik barang meminta kembali barang yang dititipkan kepadanya, tetapi orang yang dititipi mengingkarinya atau menahannya, maka ia wajib mengganti kerugian tersebut. (5) Orang yang menerima titipan mencampur barang wadi'ah dengan barang lainnya, maka apabila barang wadi'ah diminta oleh pemiliknya maka ia penerima wadi'ah wajib memisahkan barang wadi'ah tersebut dari barang lainnya. (6) Orang yang menerima titipan melakukan penyimpangan terhadap syarat-syarat yang ditetapkan dan disepakati dalam akad. Lihat WahbahZuhaili. Fiqh Islam waAdillatuhu, juz 4. Beirut: Dar al-Fikr, 1989. disebutkan. Seandainya dikiyaskan bahwabarang yang dititipkan adalah uang elektronik, pihak yang menitipkan adalah nasabah atau pengguna kartu Brizzi, pihak yang menerima titipan adalah bank, namun dalam wadi'ah ada rukun sighat yang mana mensyaratkan adanya ijab dan qabul pada saat pengajuan dan persetujuan yang berkaitan dengan penerbitan kartu tersebut adalah sebagai akad wadi'ah. Rukun dan syarat ini tidak terpenuhi dalam proses pengajuan kartu e-money Brizzi.

(2) Aspek tanggungjawab. Berdasarkan peraturan mengenai penggunaan kartu e-money Brizzi seperti yang telah penulis jelaskan sebelumnya, bahwa pemegang kartu e-money Brizzi masing-masing bertanggungjawab dalam menjaga uang elektronik yang terdapat dalam kartu tersebut. Kehilangan dan kerugian akibat keteledoran penggunaan uang dalam kartu Brizzi sepenuhnya menjadi tanggungjawab pemilik, bukan tanggungjawab pihak penerbit kartu seperti bank atau merchants. Dari sini penulis berpendapat bahwa mekanisme penggunaan kartu e-money Brizzi tidak sesuai dengan teori wadi'ah dalam Hukum Ekonomi Syariah.

(3) Konsep wadi'ah yad amanah dan wadi'ah yad dhamanah. Konsep ini apabila dikaitkan dengan mekanisme penggunaan kartu e-money Brizzi maka akan tampak tidak sejalan. Karena pada wadi'ah yad amanah tidak ada upah bagi pihak yang dititipi, sedangkan kenyataannya dalam penggunaan kartu Brizzi ada ongkos administrasi bulanan yang dikenakan, meskipun dalam jumlah yang kecil. Adapun jika dikaitkan dengan konsep wadi'ah yad dhamanah, sebagaimana dijelaskan sebelumnya bahwa pihak penerbit kartu seperti bank, tidak bertanggungjawab atas hilangnya uang dalam kartu, dan untuk menjaga kartu agar tidak sampai menimbulkan kerugian sepenuhnya diserahkan kepada para pemegang kartu masing-masing. Hal tersebut tidak sesuai dengan konsep wadi'ah yad dhamanah yang menuntut 
pihak yang dititipi untuk mengganti kerugian apabila terjadi kehilangan.

Berdasarkan uraian di atas dapat pennulis katakan bahwa penggunaan kartu e-money Brizzi tidak sesuai dengan konsep wadi'ah, baik wadi'ah yad amanah maupun wadi'ah yad dhamanah.

\section{Penggunaan E-money Brizzi Menurut Teori Qardh \\ Qardh merupakan upaya}

memberikan pinjaman kepada orang lain dengan syarat pihak peminjam mengembalikannya sesuai dengan waktu yang disepakati, maupun dalam keadaan tertentu. Dalam kontek sini qardh dikatakan sebagai perbuatan memotong sebagian, yang artinya dipinjamkan kepada orang lain. Hal ini sejalan dengan makna qardh dalam arti bahasa yang berasal dari kata qaradha yang memiliki sinonim qatha'a yang artinya memotong. Hal ini karena orang yang memberikan utang memotong sebagian dari hartanya untuk diberikan kepada orang yang menerima utang (muqtaridh).

Secara istilah qardh adalah harta yang diberikan kepada orang lain dari mâlmitslî untuk kemudian dibayarkan atau dikembalikan. Dengan kata lain qardh adalah suatu perjanjian yang khusus untuk menyerahkan harta kepada orang lain untuk kemudian dikembalikan persis seperti yang diterima. Qardh juga dapat didefinisikan sebagai pemberian harta kepada orang lain yang dapat ditagih atau diminta kembali. Dalam literature fiqh, qardh dikategorikan sebagai akad ta'awwuni atau akad yang berorientasi pada perbuatan saling membantu dan bukan transaksi komersial. ${ }^{13}$

Qardh merupakan perbuatan yang dianjurkan yang akan diber iimbalan oleh Allah swt. Hal ini sebagaimana yang dijelaskan dalam Hadis Nabi SAW bahwa memberikan utang atau pinjaman dua kali nilainya sama dengan memberikan

\footnotetext{
${ }^{13}$ Ismail Nawawi, Fikih Muamalah, 178.
}

sedekah satu kali. ${ }^{14}$ Artinya bahwa qardh (memberikan pinjaman) merupakan perbuatan yang terpuji karena dapat meringankan beban orang lain. Di antara hikmah dari qardh adalah dapat membantu orang lain yang membutuhkan pinjaman. Dari sisi pemberi pinjaman pun qardh dapat menumbuhkan rasa ingin menolong orang lain sehingga ia peka terhadap kesulitan orang yang membutuhkan pertolongannya.

Agar transaksi qardh dapat dikatakan sah maka harus memenuhi beberapa rukun dan persyaratan yang ditetapkan oleh para ulama fiqh. Adapun rukun-rukun qardh adalah: (a) Adanya pemilik barang atau harta. (b) Adanya peminjam atau pihak yang menerima barang atau harta dari pihak yang memberikan pinjaman. (c) Adanya objek qardh, yaitu barang yang dipinjamkan. (d) Adannya sighat atau ucapan ijab dan qabul yang membedakan antara akad qardh dengan akad-akad lainnya.

Adapun syarat-syarat yang harus terpenuhi sehingga qardh dapat dianggap sah antara lain: (a) Besarnya pinjaman harus dapat diketahui dengan takaran, timbangan, atau jumlahnya. (b) Sifat pinjaman dan usia atau jangka waktu pinjaman harus diketahui oleh kedua belah pihak yang melakukan akad. (c) Pinjaman tidak sah manakala akad tersebut dilakukan oleh orang yang kurang akalnya/gila/tidak ada kesadaran.

Qardh memiliki beberapa sifat di antaranya: (a) Qardh menghasilkan penetapan pemilikan. Jika seseorang meminjamkan sebuah mobil, maka orang yang dipinjami berhak menyimpan, memanfaatkan, serta mengembalikannya di kemudian hari. (b) Islam mengajarkan bahwa pemberian pinjaman tidak dikaitkan dengan syarat lainnya berupa manfaat yang harus diberikan oleh sipeminjam kepada orang yang memberikan pinjaman. Dengan kata lain, qardh tidak boleh

${ }^{14}$ Lihat Muhammad bin Ali Al-Syaukani. Nailul Authar, juz 5. (Ttp: Dar al-Fikr, tth), 347. 
menjadi syarat akad lain, seperti jual beli. Misalnya seorang penjual bersedia meminjamkan barang yang dibutuhkan tetangganya dengan syarat sipeminjam berbelanja di tempatnya. ${ }^{15}$

Menurut hasil analisis yang penulis lakukan, mekanisme penggunaan kartu emoney Brizzi tidak sesuai dengan teori qardh berdasarkan beberapa argumentasi berikut:

1. Tidak terpenuhinya salah satu rukun dan syarat keabsahan qardh, yaitu sighat yang jelas. Dalam qardh diharuskan adanya ijab qabul karena qardh adalah suatu akad kepemilikan harta, sehingga akad tersebut tidak sah kecuali dengan adanya ijab dan qabul, sama seperti akad jual beli dan hibah. Selain itu sighat yang dimaksud haruslah dapat menunjukkan bahwa akad yang dimaksudkan adalah akad qardh yang membedakannya dengan akad-akad lainnya. Hal tersebut tidak ada dalam proses pengajuan hingga penggunaan kartu e-money Brizzi.

2. Para ulama sepakat tentang kepemilikan harta akibat akad qardh. Menurut Imam Abu Hanifah dan Imam Muhammad, qardh baru berlaku dan mengikat jika barang atau harta telah diterima. Apabila seseorang meminjam sejumlah uang dan ia telah menerimanya maka uang tersebut menjadi miliknya, dan ia wajib mengembalikannya dengan jumlah uang yang sama. Menurut pendapat yang shahih dari mazhab Syafi'iyah dan Hanabilah, kepemilikan dalam qardh berlaku apabila barang telah diterima. Artinya barang atau harta yang diberikan kepada orang yang meminjam, setelah terjadi akad qardh maka barang tersebut telah resmi menjadi milik orang yang meminjam, dan orang tersebut wajib mengembalikannya kepada orang yang memberikan pinjaman tersebut. ${ }^{16}$

Dilihat darikonsep tersebut maka dapat dilihat perbedaan fundamental antara teori qardh dengan system penggunaan

\footnotetext{
${ }^{15}$ Ismail Nawawi, Fikih Muamalah, 179-180.

${ }^{16}$ WahbahZuhaili, Fiqh Islam, jus 4, 724.
}

kartu e-money Brizzi dimana dalam qardh setelah akad diucapkan maka barang atau harta yang menjadi objek qardh secara otomatis telah menjadi milik pihak yang menerima pinjaman tersebut. Sedangkan dalam system penggunaan kartu e-money Brizzi, uang elektronik yang ada di dalam kartu tersebut tetap menjadi milik pemegang kartu, tidak secara otomatis menjadi milik bank atau merchants sebagai penerbit kartu Brizzi tersebut. Sehingga tampaklah perbedaan antara teori qardh dengan mekanisme penggunaan kartu Brizzi.

3. dalam fiqh muamalah pada ulama sepakat bahwa setiap utang yang mengambil manfaat maka hukumnya haram. Sehingga dalam akad qardh pemberi pinjaman tidak diperbolehkan mengambil keuntungan dari barang yang dipinjamkan. Hal ini berbeda dengan mekanisme sistem penggunaan kartu emoney Brizzi dimana tidak ada kejelasan tentang dana yang tersimpan di kartu emoney Brizzi, apakah digunakan untuk kepentingan bank - sebagaimana dana dalam kartu ATM - atau tidak, maka dalam hal ini tidak ada kejelasan dari pihak pengelola e-money Brizzi.

\section{Berdasarkan analisis di atas, maka dapat ditegaskan bahwa sistem penggunaan kartu e-money Brizzi tidak sesuai dengan teori qardh dalam Hukum Ekonomi Syariah.}

Namun demikian, terlepas dari penjelasan di atas, berbagai masalah riil seringkali muncul di masyarakat akibat dari penggunaan kartu e-money Brizzi tersebut. Di antaranya adalah:

1. Bagi masyarakat yang merasa lebih nyaman menggunakan uang tunai dalam bertransaksi, seperti ada pemaksaan untuk menggunakan kartu e-money Brizzi jika hendak menggunakan fasilitas umum yang menetapkan penggunaan e-money Brizzi seperti sarana transportasi Transjakarta, atau di beberapa pelabuhan tertentu yang menetapkan peraturan tersebut. 
2. Gagal transaksi, gagal top up, adalah hal yang biasa terjadi dalam system transaksi online atau e-money, tetapi hal tersebut seringkali membuat urusan menjadi rumit. Kepentingan yang semestinya harus terselesaikan menjadi tertunda, dan dapat memakan waktu dan tenaga lebih besar akibat dari gagalnya system transaksi online yang menggunakan e-money, termasuk e-money Brizzi.

3. Bagi pemegang kartu e-money Brizzi, ternyata tidak semua fasilitas umum termasuk tempat perbelanjaan menyediakan fitur pembayaran dengan kartu e-money Brizzi, sehingga dalam kondisi tersebut membuat kartu Brizzi kehilangan fungsinya.

Beberapa permasalahan tersebut selayaknya menjadi perhatian bagi pihak penerbit kartu e-money Brizzi terutama pihak Bank BRI agar segera dapat dilakukan langkah-langkah perbaikan kedepan.

\section{KESIMPULAN}

Berkaitan dengan penggunaan kartu e-money Brizzi apabila dilihat dari aspek ini maka sebenarnya penggunaan kartu tersebut telah memenuhi persyaratan sahnya ijab dan qabul menurut Hukum Ekonomi Syariah, karena meskipun dalam transaksi yang menggunakan alat pembayaran kartu Brizzi tersebut tidak didapati ijab dan qabul secara lisan, tulisan, maupun isyarat, namun perbuatan melakukan pembayaran dengan kartu tersebut secara substansif telah menunjukkan adanya kesepakatan antara merchants dengan pengguna kartu tersebut.Selain itu penggunaan kartu emoney Brizzi apabila ditinjau dari aspek perkara-perkara yang membatalkan keabsahan hukum jual beli, maka penggunaan kartu e-money Brizzi dalam transaksi jual beli tidak terdapat di dalamnya unsur-unsur yang membatalkan sebagaimaya disebutkan di atas. Adanya potongan dana administrasi akibat transaksi dengan menggunakan kartu emoney Brizzi hakekatnya adalah mewakilkan pekerjaan server dari pemegang kartu Brizzi kepada pengelola jasa server agar transaksi dapat berjalan sebagaimana mestinya. Sehingga dapat dikatakan bahwa penggunaan kartu emoney Brizzi dimana pada setiap bulannya dikenakan biaya administrasi atas penggunaan kartu tersebut memiliki keserupaan dengan sistem wakalah bilujran dalam Hukum Ekonomi Syariah.

Namun demikian, beradasarkan hasil analisis yang penulis lakukan ditemukan bahwa penggunaan kartu e-moneyBrizzi apabila dilihat dari sudut pandang teori wadi'ah, menurut penulis tidak sesuai dengan teori wadi'ah karena tidak terpenuhinya syarat dan rukun wadi'ah, juga tidak sejalan dengan konsep wadi'ah yad amanah dan wadi'ah yad dhamanah dari aspek beban tanggung jawabnya bagi pihak yang dititipi. Disamping itu penggunaan kartu e-money Brizzi juga tidak sesuai dengan teori qardh. Hal inikarenaselain tidak terpenuhinya salah satu rukun dan syarat keabsahan qardh, juga dalam qardh setelah akad diucapkan maka barang atau harta yang menjadi objek qardh secara otomatis telah menjadi milik pihak yang menerima pinjaman tersebut. Sedangkan dalam sistem penggunaan kartu e-money Brizzi, uang elektronik yang ada di dalam kartu tersebut tetap menjadi milik pemegang kartu.

\section{DAFTAR PUSTAKA}

Abd Hadi. MemahamiAkad-AkadDalamPerbankan Syariah dan Dasar-Dasar Hukumnya. Surabaya: SinarTerang, 2015.

Abdul Manan, Hukum Ekonomi Syariah DalamPerspektifKewenanganPeradilan Agama, Jakarta: Kencana, 2016. 
Abdurrahman al-Jaziri, Kitab Fiqh 'Ala Mazhab al-Arba'ah, juz, 3, Beirut: Dar al-Fikr, tth.

Ali Fikri, Al-Mu'amalah al-Maddiyahwa Al-Adabiyah, juz 2, Mesir: Musthafa al-Halabiy, 1939.

Faozan Amar, Ekonomi Islam, SuatuPengantar, (Jakarta: Uhamka Press, 2016.

Faturrahman Djamil. Kompilasi Hukum Perikatan dalam Mariam Darus Badrulzaman. Bandung: Citra Aditya Bakti, 2001.

Lexi J. Moleong, Metodologi Penelitian Kualitatif. Bandung: Rosda Karya, 2007.

M. Iqbal Hasan, Metodologi Penelitian dan Aplikasinya. Bogor: Ghalia Indonesia, 2002.

Moch. Achsan Rumi. Perlindungan Hukum Bagi Pengguna Aplikasi Mobile Payment BBM Money. Makassar: Universitas Hasanudin, 2015.

Muhammad Nazir, Metode Penelitian, Jakarta: Ghalia Indonesia, 1998.

Muhammad, system dan Prosedur Oprasional Perbankan Syari'ah, Yogyakarta: UII Press, 2000.

Peter Mahmud Marzuki, Penelitian Hukum. Jakarta: Kencana Prenada Media Group, 2011.

RachmatSyafe'i. FiqhMuamalah. Bandung: Pustaka Setia, 2001.

Samsuddin Ibn Qudamah al-Maqdisi. Al-Syarh al-Kabir, juz 2. ttp: Dar al-Fikr, tt.

SayidSabiq. Fiqh al-Sunnah. Juz 3, Beirut: Dar al-Fkir, 1981.

Sugiyono,MetodePenelitianKuantitatifKualitatif Dan $R \&$ D. Bandung: Alfabeta, 2008.

Syamsuddin Muhammad al-Ramli, Nihayah al-Muhtaj, juz 3, Beirut: Dar al-Fikr, 2004.

WahbahZuhaili, Fiqh Islam waAdillatuh, juz 5, Damascus: Dar al-Fikr, 1986. 